\title{
Efficacy of misoprostol over dinoprostone gel as a cervical ripening agent: a comparative study
}

\author{
Pankajkumar B. Nimbalkar ${ }^{1}$, Jaldhara N. Patel ${ }^{2 *}$, Nilesh Thakor ${ }^{3}$
}

\begin{abstract}
${ }^{1}$ Department of Obstetrics and Gynecology, GMERS Medical College, Dharpur-Patan, Gujarat, India ${ }^{2}$ Department of Obstetrics and Gynecology, GMERS Medical College, Gandhinagar, Gujarat, India. ${ }^{3}$ Department of Community Medicine, GMERS Medical College and Hospital, Gandhinagar Gujarat, India
\end{abstract}

Received: 14 October 2017

Accepted: 24 October 2017

\author{
*Correspondence: \\ Dr. Jaldhara N. Patel, \\ E-mail: researchforbetterhealth@gmail.com
}

Copyright: $(\mathcal{C}$ the author(s), publisher and licensee Medip Academy. This is an open-access article distributed under the terms of the Creative Commons Attribution Non-Commercial License, which permits unrestricted non-commercial use, distribution, and reproduction in any medium, provided the original work is properly cited.

\section{ABSTRACT}

Background: Timely induction of labour could reduce maternal mortality and morbidity as well as assure a delivery of healthy baby. The objective of this study was to evaluate the efficacy of Misoprostol as a cervical ripening agent and its comparison with Dinoprostone gel in terms of success rate, safety, side effects and patient compliance.

Methods: A total of 250 pregnant women requiring induction of labor were recruited. Out of 250 cases, 150 were induced with 50 microgram Misoprostol and 100 cases with $0.5 \mathrm{mg}$ intracervical Dinoprostone gel during September 2014 to August 2017 at the department of Obstetrics and Gynaecology, GMERS Medical College, Dharpur-Patan. Written and informed consent was taken from the patients. Outcome measures, such as change in Bishop's score, need of augmentation, induction delivery interval; complications like hyperstimulation, fever and meconium passage were compared between two groups. Statistical analysis was performed by Epi Info 7.

Results: Age range of the patients was 21 to 35 years. $74.8 \%$ of the patients were in $21-25$ years age groups. $50.4 \%$ patients were multigravida. $57.6 \%$ patients had more than 37 weeks of pregnancy. $50.4 \%$ of the patients had premature rupture of membrane as indication of labour. The mean Bishop's score for induction was 3.21 in Misoprostol group. 81.3\% patients in Misoprostol group and 93\% of patients in Dinoprostone group were delivered by vaginal delivery. 60\% patients delivered within 6 hours in Misoprostol group. (Misoprostol: 60\%, Dinoprostone: $27 \%, \mathrm{p}<0.001)$. Incidence of thin meconium was $11.3 \%$ in Misoprostol group, $9 \%$ in Dinoprostone group. In Misoprostol group 3.3 women had fever after induction.

Conclusions: Vaginal misoprostol is more efficacious in cervical ripening and for induction of labor than Dinoprostone.

Keywords: Bishop's score, Cervical ripening, Dinoprostone, Induction of labour, Misoprostol

\section{INTRODUCTION}

Induction of labour is a well-established obstetric concept since ancient times. Induction is warranted when the benefits to either the mother or foetus outweigh those of continuing pregnancy. Induction of labour is defined as iatrogenic stimulation of uterine contraction to accomplish delivery prior to the onset of spontaneous labour aimed at delivery by vaginal route. A delicate balance between uterine activity, cervical dilatation rate and response of the foetus should be sought to achieve successful induction of labour. Timely induction could reduce maternal mortality and morbidity as well as assure a delivery of healthy baby. Induction of labour involves a complete interaction between oxytocin and prostaglandins and success of labour depends on cervical condition like dilatation, effacement, consistency and position in the pelvis. ${ }^{1,2}$ 
Prostaglandins as pharmacological agents have always fascinated the obstetrician for induction of labour as well as cervical ripening agent. Up till now, 2 types of prostaglandins PGE2 and PGF2 were used in obstetrics. Recently a new prostaglandin came into use in obstetrics for labour induction. PGE1 methyl analogue Misoprostol. This was used initially for treatment of gastric ulcers due to NSAIDS. Due to its uterotonic effect and cervical ripening effect, its use in obstetrics for labour induction are increasing now a days. ${ }^{1}$

Present study is to evaluate the efficacy of Misoprostol as a cervical ripening agent and its comparison against PGE2 Dinoprostone gel in terms of success rate, safety, side effects, patient compliance and cost factor.

\section{METHODS}

This prospective study was carried out in 250 cases with gestational age equal to or greater than 28 weeks, no uterine activity at the time of induction, Cervical dilatation should be less than $3 \mathrm{~cm}$ and effacement should be less than $50 \%$, positive non stress test without having history of antepartum hemorrhage, cesarean section and allergy to prostaglandins selected by purposive sampling method during September 2014 to August, 2017 at the Department of Obstetrics and Gynaecology, GMERS Medical College, Dharpur-Patan.

The procedure, possible complications and chances of failure of the procedure were explained to each patient in detail. Written and informed consent was taken from the patient. Before conducting the study, approval was obtained from institutional ethical committee for human research. Data safety and confidentiality was also given due consideration. The file containing identity related details was kept password protected and the filled Performa were kept in lock with key accessible only to researcher.

Out of 250 cases, 150 were induced with 50 microgram Misoprostol and 100 cases with $0.5 \mathrm{mg}$ intracervical Dinoprostone gel. Patients with cardiovascular disease, bronchial asthma, renal or hepatic disorders. Cephalopelvic disproportion, low lying placenta, acute local cervical lesion and previous lower segment caesarean section or any scar over the uterus were excluded from study.

Information regarding socio demographic profile, duration of pregnancy, labor pain, leaking per vaginum, fetal movement and any obstetric or medical disorders was collected using predesigned, pretested performa. Patients were examined and evaluated using investigation like hemoglobin, urine albumin and sugar and blood group blood urea, plasma fibrinogen, bleeding time, clotting time. Prophylactic antibiotics were given to all the patients. After induction, patient was monitored for vital signs, uterine activity, fetal heart sound and progress of labour and development of any untoward reaction.
Data was collected and analyzed statistically using Epi Info 7.

\section{RESULTS}

Age range of the patients was 21 to 35 years. $76.7 \%$ of the patients were in 21-25 years age groups (Table1).

Table 1: Distribution of patients according to their age groups.

\begin{tabular}{|llll|}
\hline $\begin{array}{l}\text { Age group } \\
\text { (year) }\end{array}$ & $\begin{array}{l}\text { Misoprostol } \\
(\mathbf{n = 1 5 0 )}\end{array}$ & $\begin{array}{l}\text { Dinoproston } \\
\text { gel }(\mathbf{n = 1 0 0 )})\end{array}$ & $\begin{array}{l}\text { Total } \\
(\mathrm{n}=250)\end{array}$ \\
\hline $21-25$ & $115(76.7 \%)$ & $72(72 \%)$ & $\begin{array}{l}187 \\
(74.8 \%)\end{array}$ \\
\hline $26-30$ & $32(21.3 \%)$ & $18(18 \%)$ & $50(20.0 \%)$ \\
\hline $31-35$ & $03(2.0)$ & $10(6 \%)$ & $13(5.2 \%)$ \\
\hline $\begin{array}{l}\text { Mean age } \\
\text { in year }\end{array}$ & 24.38 & 24.52 & 24.44 \\
\hline
\end{tabular}

Out of total 250 pregnant women 126 (50.4\%) women were multigravida and $144(57.6 \%)$ patients had more than 37 weeks of pregnancy (Table 2).

Table 2: Distribution of patients according to gravidity and weeks of gestation.

\begin{tabular}{|llll|}
\hline Gravidity & $\begin{array}{l}\text { Misoprostol } \\
(\mathrm{n}=150)\end{array}$ & $\begin{array}{l}\text { Dinoprostone } \\
\text { gel } \\
(\mathrm{n}=100)\end{array}$ & $\begin{array}{l}\text { Total } \\
(\mathrm{n}=\mathbf{2 5 0})\end{array}$ \\
\hline Primigravida & $73(48.7 \%)$ & $51(51 \%)$ & $\begin{array}{l}124 \\
(49.6 \%)\end{array}$ \\
\hline Multigravida & $77(51.3 \%)$ & $49(49 \%)$ & $\begin{array}{l}126 \\
(50.4 \%)\end{array}$ \\
\hline Weeks of gestation & & 18 \\
\hline$<32$ weeks & $12(8 \%)$ & $6(6 \%)$ & $(7.2 \%)$ \\
\hline $32-36$ weeks & $48(32 \%)$ & $40(40 \%)$ & $\begin{array}{l}88 \\
(35.2 \%)\end{array}$ \\
\hline$>37$ weeks & $90(60 \%)$ & $54(54 \%)$ & $\begin{array}{l}144 \\
(57.6 \%)\end{array}$ \\
\hline
\end{tabular}

Out of total 250 women $126(50.4 \%)$ of the women had premature rupture of membrane followed by $59(23.6 \%)$ had post maturity as indication of labour (Table 3 ).

The mean Bishop's score for induction was 3.21 in study group and 3.25 in control group (Table 4).

Only $12 \%$ of the patients required augmentation in study group while it was $48 \%$ in Dinoprostone group.

Out of total 250 women $122(81.3 \%)$ women in Misoprostol group and $93 \%$ of women in Dinoprostone group were delivered by vaginal delivery (Table 5).

After application of intravaginal Misoprostol $50 \mu \mathrm{g}$ tablet, $60 \%$ patients delivered within 6 hours. The minimum induction delivery interval was 2 hours. In 
Dinoprostone gel group, maximum patients required 6-12 hours for delivery after induction, minimum induction delivery interval was 3 hours-40 minutes (Table 6).

Table 3: Distribution patients according to indication of labour.

\begin{tabular}{|llll|}
\hline $\begin{array}{l}\text { Indication } \\
\text { Premature }\end{array}$ & $\begin{array}{l}\text { Misoprostol } \\
(\mathrm{n}=150)\end{array}$ & $\begin{array}{l}\text { Dinoprostone } \\
\text { gel }(\mathrm{n}=100)\end{array}$ & $\begin{array}{l}\text { Total } \\
(\mathrm{n}=250)\end{array}$ \\
$\begin{array}{l}\text { rupture of } \\
\text { membrane }\end{array}$ & $71(47.3 \%)$ & $55(55 \%)$ & $\begin{array}{l}126 \\
(50.4 \%)\end{array}$ \\
\hline $\begin{array}{l}\text { Post } \\
\text { maturity }\end{array}$ & $34(22.6 \%)$ & $25(25 \%)$ & $\begin{array}{l}59 \\
(23.6 \%)\end{array}$ \\
\hline $\begin{array}{l}\text { Pre- } \\
\text { eclamptic } \\
\text { toxaemia }\end{array}$ & $18(12.0 \%)$ & $12(12 \%)$ & $\begin{array}{l}30 \\
(12.0 \%)\end{array}$ \\
\hline $\begin{array}{l}\text { Eclampsia } \\
\text { Intra }\end{array}$ & $4(2.6 \%)$ & $2(2 \%)$ & $\begin{array}{l}6 \\
(2.4 \%)\end{array}$ \\
\hline $\begin{array}{l}\text { uterine } \\
\text { fetal death }\end{array}$ & $6(4.0 \%)$ & $4(4 \%)$ & $\begin{array}{l}10 \\
(4.0 \%)\end{array}$ \\
$\begin{array}{l}\text { Intra } \\
\text { uterine } \\
\text { growth } \\
\text { retardation }\end{array}$ & $10(6.6 \%)$ & $1(1 \%)$ & $\begin{array}{l}11 \\
(4.4 \%)\end{array}$ \\
\hline $\begin{array}{l}\text { Congenital } \\
\text { anomalous } \\
\text { baby }\end{array}$ & $7(4.6)$ & $1(1 \%)$ & 8 \\
\hline
\end{tabular}

Table 4: Distribution of patients according to Bhishop's score at the time of induction.

\begin{tabular}{|l|l|l|}
\hline Bishop's Score & $\begin{array}{l}\text { Misoprostol } \\
(\mathbf{n}=150)\end{array}$ & $\begin{array}{l}\text { Dinoprostone } \\
\text { gel }(\mathbf{n}=100)\end{array}$ \\
\hline 2 & $32(21.3 \%)$ & $25(25 \%)$ \\
\hline 3 & $62(41.3 \%)$ & $26(23 \%)$ \\
\hline 4 & $54(36.0 \%)$ & $49(49 \%)$ \\
\hline 5 & $02(1.4 \%)$ & $3(3 \%)$ \\
\hline Mean Bishop's Score & 3.21 & 3.25 \\
\hline
\end{tabular}

Table 5: Distribution of patient according to their mode of delivery.

\begin{tabular}{|llll|}
$\begin{array}{l}\text { Mode of } \\
\text { delivery }\end{array}$ & $\begin{array}{l}\text { Misoprostol } \\
(\mathbf{n}=\mathbf{1 5 0})\end{array}$ & $\begin{array}{l}\text { Dinoprostone } \\
\text { gel }(\mathbf{n = 1 0 0 )}\end{array}$ & $\begin{array}{l}\text { Total } \\
(\mathbf{n}=250)\end{array}$ \\
\hline $\begin{array}{l}\text { Vaginal } \\
\text { Forceps }\end{array}$ & $08(5.3 \%)$ & $05(5 \%)$ & $215(86.0 \%)$ \\
/vacuum & & $93(93 \%)$ & $13(5.2 \%)$ \\
\hline LSCS & $20(13.3 \%)$ & $02(2 \%)$ & $22(8.8 \%)$ \\
\hline
\end{tabular}

$11.3 \%$ of patients had thin meconium and $15.3 \%$ of patients demonstrated thick meconium in study group compared to $9 \%$ thin meconium and $18 \%$ thick meconium in Dinoprostone group (Table 7).

In study group 5 patients had fever after induction. There was a single spike of fever of $100^{\circ} \mathrm{F}$ which responded to oral paracetamol and cold sponging. No patient had diarrhoea and vomiting. Incidence of cervical tear and vaginal laceration was comparable in both groups. No case of hyper stimulation was observed in the present study (Table 8).

Table 6: Distribution of patients according to induction delivery interval.

\begin{tabular}{|llll|}
\hline Hours & $\begin{array}{l}\text { Misoprostol } \\
(\mathrm{n}=150)\end{array}$ & $\begin{array}{l}\text { Dinoprostone } \\
\text { gel }(\mathrm{n}=100)\end{array}$ & $\begin{array}{l}\text { Total } \\
(\mathrm{n}=\mathbf{2 5 0})\end{array}$ \\
\hline $0-6$ & $90(60.0 \%)$ & $27(27 \%)$ & $117(46.8 \%)$ \\
\hline $6-12$ & $52(34.6 \%)$ & $44(44 \%)$ & $96(38.4 \%)$ \\
\hline $12-24$ & $08(5.3 \%)$ & $29(29 \%)$ & $37(14.8 \%)$ \\
\hline
\end{tabular}

Chi square: 38.03; Degree of freedom: $2 ; \mathrm{p}<0.0001$

Table 7: Distribution of patients according incidence of meconium in each group at the time of delivery.

\begin{tabular}{|llll} 
Meconium & $\begin{array}{l}\text { Misoprostol } \\
(\mathbf{n}-150)\end{array}$ & $\begin{array}{l}\text { Dinoprostone } \\
\text { gel }(\mathbf{n}=100)\end{array}$ & $\begin{array}{l}\text { Total } \\
(\mathbf{n}=250)\end{array}$ \\
$\begin{array}{l}\text { Thin } \\
\text { Meconium }\end{array}$ & $17(11.3 \%)$ & $09(09 \%)$ & $\begin{array}{l}26 \\
(10.4 \%)\end{array}$ \\
$\begin{array}{l}\text { Thick } \\
\text { Meconium }\end{array}$ & $23(15.3 \%)$ & $18(18 \%)$ & $\begin{array}{l}41 \\
(16.4 \%)\end{array}$ \\
\hline $\begin{array}{l}\text { No } \\
\text { Meconium }\end{array}$ & $110(73.3 \%)$ & $73(73 \%)$ & $\begin{array}{l}183 \\
(73.2 \%)\end{array}$ \\
\hline
\end{tabular}

Table: 8 Distribution of patients according to their complication.

\begin{tabular}{|lll|}
\hline Complication & $\begin{array}{l}\text { Misoprostol } \\
(\mathrm{n}=150)\end{array}$ & $\begin{array}{l}\text { Dinoprostone } \\
\text { gel }(\mathrm{n}=100)\end{array}$ \\
\hline Fever & $05(3.3 \%)$ & 0 \\
\hline Cervical tear & $07(4.6 \%)$ & $05(5 \%)$ \\
\hline Vaginal laceration & $02(1.3 \%)$ & $03(3 \%)$ \\
\hline
\end{tabular}

\section{DISCUSSION}

Age definitely influence labour. Pregnancy below 20 years has more complications as mother is also in developing phase. While increasing age increases the resistance of cervix for dilatation and so ripening of cervix will be delayed or failed in case of primigravida women aged more than 35 years. ${ }^{1}$

In present study, no pregnancies were reported below 20 years and above 36 years of age and maximum patients were in age group of 20-30 years. In Jani PS et al, age range of the patients was 20-35 years age group with maximum patients was in the age group of 20-30 years. ${ }^{1}$ In David B et al, $40.7 \%$ patients were above the age of 30 year compared to only $4 \%$ patients in present study. ${ }^{3}$

In present study, maximum patients (i.e. 50.4\%) requiring induction had PROM as an indication compared to $46.6 \%$ and $1.4 \%$ patients in Jani PS et al and Howard B study respectively. ${ }^{1,4}$ In present study $23.6 \%$ women had post maturity as indication of induction of labor and in Jani PS et al, Howard B and Kolderupet L al it was 24\%, 35\% and $57.9 \%$ respectively. ${ }^{1,4,5}$ 
Bishop's score at the time of induction is a very important factor determining successful outcome of labour. Increase in the Bishop's score increases the success of outcome of induction of labour.

In study group, maximum number of patients $41.3 \%$ were induced in Bishop's score of 3. In control group, maximum patients around $49 \%$ were induced in Bishop's score of 4 .

In study group $36.0 \%$ of patients were induced with Bishop's score 4 and $21.3 \%$ patients were induced with Bishop's score 2 and only $1.4 \%$ of patients had Bishop's score 5. The mean Bishop's score for induction was 3.21 in study group and was similar to that of control group. Similar results were also obtained in Jani PS et al. ${ }^{1}$

In David B, Blanchette and Kolderup et al, requirement of augmentation is less in misoprostol group i.e. 50$63 \% .^{3-5}$ In present study $60 \%$ women delivered within 6 hours in misoprostol group and $27 \%$ patients in Dinoprostone group. In Jani PS et al $57.4 \%$ women delivered within 6 hours in misoprostol group and $28 \%$ patients in Dinoprostone group. ${ }^{1}$

In David B et al $88 \%$ patients delivered within 24 hours in misoprostol group and $49.3 \%$ patients in Dinoprostone group. ${ }^{3}$ In Blanchette, Kolderup and Deborah W et al more than $70 \%$ patients in misoprostol group delivered within 24 hours and less than $50 \%$ patients in Dinoprostone group delivered within 24 hours. $^{4-6}$ In Deborah W et al $8.8 \%$ of patients in misoprostol group demonstrated thin meconium and $19.2 \%$ of patients demonstrated thick meconium at the time of delivery. ${ }^{6}$

In Garry D et al the interval from start of induction to vaginal delivery $(794.5 \pm 408$ minutes versus $1005.3 \pm 523$ minutes; $\mathrm{p}<0.02$ ) was significantly shorter in the misoprostol group. ${ }^{7}$ Women receiving misoprostol were more likely to deliver vaginally both in $<12 \mathrm{~h}(44 \%$ versus $12 \%$; $\mathrm{p}<0.0001)$ and $<24 \mathrm{~h}(68 \%$ versus $38 \%$; $<0.001)$. In Agrawal $\mathrm{N}$ et al Bishop score rise, after 6 hours of initiation of therapy was significantly higher in the misoprostol group than Dinoprostone, 2.98 \pm 2.57 versus $2.05 \pm 1.83(\mathrm{p}=0.04){ }^{8}$

The need of oxytocin augmentation was reduced in misoprostol versus Dinoprostone group, $16.6 \%$ versus $78.3 \%(\mathrm{p}=<0.001)$. Induction delivery interval was shorter in misoprostol; $12.8 \pm 6.4 \mathrm{~h}$ versus $18.53 \pm 8.5 \mathrm{~h}$ in Dinoprostone group $(\mathrm{p}=<0.01)$.

In Ozkan $\mathrm{S}$ et al, time interval from induction to vaginal delivery was found to be significantly shorter in misoprostol group when compared to Dinoprostone subjects $(680 \pm 329$ minutes versus $1070 \pm 435$ minutes, $\mathrm{P}$ $<0.001) .{ }^{9}$ Vaginal delivery rates within $12 \mathrm{~h}$ were found to be significantly higher with misoprostol induction [ $\mathrm{n}=$ $37(66 \%)$ versus $\mathrm{n}=25$ (44.6\%); $\mathrm{p}=0.02]$, whereas vaginal delivery rates in $24 \mathrm{~h}$ did not differ significantly between groups $[\mathrm{n}=41(73.2 \%)$ versus $\mathrm{n}=36(64.2 \%) ; \mathrm{p}$ $=0.3]$. More subjects required oxytocin augmentation in Dinoprostone group $[\mathrm{n}=35(62.5 \%)$ versus $\mathrm{n}=20$ $(35.7 \%), p=0.005]$ and cardiotocography tracings revealed early decelerations occurring more frequently with misoprostol induction $(10.7$ versus $0 \%, \mathrm{p}=0.03)$.

However, study done in single college of Dharpur-Patan city limits us to generalize the results. There is definitely a need for well-planned, large-scale studies using standardized methodologies to evaluate the efficacy of Misoprostol as a cervical ripening agent and its comparison with Dinoprostone gel in terms of success rate, safety, side effects and patient compliance.

\section{CONCLUSION}

Vaginal misoprostol is safe and effective for induction of labor with lesser need of oxytocin augmentation and shorter induction delivery interval and may have some advantages compared to Dinoprostone including improved efficacy, lesser adverse effect and lower cost of the drug.

\section{Funding: No funding sources}

Conflict of interest: None declared

Ethical approval: The study was approved by the Institutional Ethics Committee

\section{REFERENCES}

1. Jani PS, Gandhi MR, Thakor N. Efficacy of misoprostol over dinoprostone gel and Foley's catheter as a cervical ripening agent. Int J Med Sci Public Health. 2015;4:888-92.

2. Melanie PM, Martin SL, Suzanne L. Uterine rupture associated with use of misoprostol in gravid patient with previous cesarean section. Am J Obst Gynecol. 1999; 180:1535-42.

3. David B, Mora G, Arias F. A randomized comparison between misoprostol and dinoprostone for cervical ripening and labour induction in patient with unfavorable cervices. Obst Gynecol. 1997:89:581-5.

4. Howard BA, Nayak S. Comparison of the safety and efficacy of intra vaginal misoprostol with those of prostaglandin E2 for cervical ripening and induction of labour. Am J ObstGynecol. 1999;180:1551-9.

5. Kolderup L, Mclean L. Misoprostol is more efficacious for labour induction than prostagiandinE2 but is it associated with more risk? Am J Obst Gynecol. 1999;180:1543-50.

6. Deborah WA, Johnes MM. A comparison of misoprostol and PGE2 gel for preinduction cervical ripening and labour induction. Am J Obst Gynecol. 1995;172:1804-10.

7. Garry D, Fiqueroa R, Kailash RB. Randomized controlled trial of vaginal misoprostol versus dinoprostone vaginal insert for labour induction. J Matern Fetal Neonatal Med. 2003;13(4):254-9. 
8. Agarwal N, Gupta A, Kriplani A, Bhatla N, Parul. Six hourly vaginal misoprostol versus intracervical dinoprostone for cervical ripening and labour induction. J Obstet Gynecol Res. 2003;29(3):147-51.

9. Ozkan S, Calişkan E, Doğer E, Yücesoy I, Ozeren S, Vural B. Comparative efficacy and safety of vaginal misoprostol versus Dinoprostone vaginal insert in labor induction at term: a randomized trial: Arch Gynecol Obstet. 2009;280(1):19-24.

Cite this article as: Nimbalkar PB, Patel JN, Thakor N. Efficacy of misoprostol over dinoprostone gel as a cervical ripening agent: a comparative study. Int $\mathbf{J}$ Reprod Contracept Obstet Gynecol 2017;6:5251-5. 